\title{
o estado fala mais alto: o telefone em belo horizonte, 1894-1912 ${ }^{\star}$ the state speaks louder: the telephone in belo horizonte, 1894-1912
}

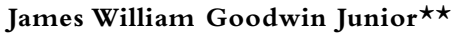 \\ Departamento de Geografia e História, Centro Federal de Educação Profissional e Tecnológica, \\ Belo Horizonte, Minas Gerais, Brasil
}

RESUMO

Este artigo investiga a implantação do sistema telefônico na nova capital de Minas Gerais, cidade construída pelo Estado como sinal de progresso e desenvolvimento. Aborda-se a tecnologia como construção social, numa perspectiva centrada em seu uso social. Da instalação dos primeiros telefones na cidade ainda em construção, em 1894, ao arrendamento do sistema instalado a uma companhia privada, em 1912, o serviço telefônico foi administrado por entes governamentais. Mais do que forças do mercado ou demandas dos consumidores, as diretrizes de Estado condicionaram e caracterizaram a incorporação daquele artefato à vida urbana local. A base documental é variada, incluindo relatórios administrativos dos prefeitos da cidade, coleções legislativas municipais e estaduais, periódicos locais (jornais e revistas) e obras memorialísticas e históricas.

Palavras-chave: Progresso. Telefone. Dirigismo estatal. Belo Horizonte. Primeira República.

\begin{abstract}
This paper investigates the telephone system's implantation in the new capital of Minas Gerais, a city built by the State as a sign of progress and development. Technology is approached here as a social construction, through a user-centered perspective. From the period of the first telephones installed in 1894, with the city still under construction, to the system's lease to a private company in 1912, government operated the telephone system. More than market forces or consumers' demands, State directives conditioned and characterized the way that artifact was incorporated into urban local life. Documental basis is diverse, including city mayors' administrative reports, municipal and state law collections, local press (newspaper and magazines), memories and historical works.
\end{abstract}

Keywords: Progress. Telephone. State dirigisme. Belo Horizonte. First Republic.

* Uma versão preliminar foi apresentada no XII CONGRESSO BRASILEIRO DE HISTÓRIA ECONÔMICA, UFF, 28-30 de agosto de 2017, Niterói, do qual participei com apoio do CEFET-MG.

Submetido: 2 de novembro de 2017; aceito: 2 de fevereiro de 2018.

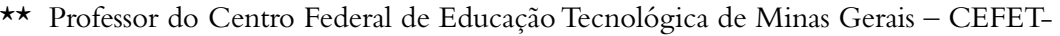
-MG. Doutor em História pela Universidade de São Paulo - USP. E-mail: jamesg@, cefetmg.br 


\section{Introdução}

O período que se estende da segunda metade do século XIX às primeiras décadas do século XX foi marcado pela criação de um sistema efetivamente mundializado de comunicação, transporte, comércio, valores e hábitos, que consolidou um modo de edificar, planejar, viver e compreender a cidade como o ambiente capaz de condensar as experiências e vivências da modernidade. Essa modernidade poderia ser traduzida na ideia de "Progresso", a qual funcionava como uma espécie de palavra-chave, a nortear tanto as decisões práticas, quanto os esforços interpretativos e avaliativos das elites cultas e, por força dos mecanismos de difusão cultural, mesmo de membros das classes menos favorecidas.

Por suas características materiais e simbólicas, os artefatos tecnológicos tornaram-se "sinais visíveis da civilização" (Goodwin, 2015, p. 25): sua presença atestava a participação e inclusão num mundo mais amplo, mais moderno, mais eficiente. Especialmente em sociedades de baixa industrialização, adquiriram um sentido quase mágico, já que poucas vezes estavam integrados a um sistema que efetivamente alterasse a composição tradicional das comunidades, quer econômica, quer socialmente.

O telefone, quando surgiu, foi saudado como parte desse conjunto de maravilhas que iria mudar, para melhor, a vida em sociedade.Todavia, a transformação daquela invenção num sistema funcional e economicamente viável exigiu grandes esforços (Fischer, 1992, p. 35-36), coroados com a rápida assimilação do telefone ao cotidiano, um dos muitos "trecos, troços e coisas" (Miller, 2013) a comporem a cultura material da sociedade burguesa industrial - ou daquelas que buscavam emulá-la. Nas palavras de um entusiasta da indústria telefônica,

tão inteiramente tem o telefone superado o ridículo com o qual, muitas pessoas hão de bem lembrar, foi ele recebido originalmente, que hoje é considerado, na maioria dos lugares, como algo dado, como se fosse parte dos fenômenos naturais deste planeta. (Casson, 2006, p. 7)

Propõe-se aqui, então, investigar a implantação do sistema telefônico na nova capital mineira, a qual nasceu associada ao discurso do progresso e do desenvolvimento. Especificamente, a relação das condições de construção da cidade como um projeto estatal e as características do seu 
sistema telefônico, uma vez que este foi implantado e administrado pelo poder público local, diferentemente do que ocorria no país, e mesmo em outras cidades de Minas Gerais. Por isso, o recorte temporal inicia-se com a instalação dos primeiros telefones em 1894, com a cidade ainda em construção, e se encerra em 1912, quando o sistema instalado é arrendado a uma companhia telefônica privada.

A abordagem proposta considera a tecnologia como construção social, enfatizando o que David Edgerton chama de "perspectiva centrada no uso":

Uma característica particularmente importante de uma história da tecnologia centrada no uso é que esta pode ser genuinamente global. Ela inclui todos os lugares que usam tecnologia, não apenas aqueles poucos lugares onde invenções e inovações estão concentradas. No relato centrado na inovação, a maioria dos lugares não tem uma história da tecnologia. Em relatos centrados no uso, quase todos têm. (Edgerton, 2008, p. xiii)

Buscam-se, pois, indícios que permitam compreender como um artefato oriundo de outro país, de contexto sociocultural diferente, foi recebido, utilizado e ressignificado na nova capital que se construía em Minas Gerais. Para tanto, uma variada base documental foi consultada, incluindo relatórios administrativos e coleções legislativas, periódicos locais, memórias pessoais e obras históricas.

\section{Estendendo os fios: a expansão do telefone}

A invenção do telefone resultou de um processo multifacetado, com vários personagens envolvidos, e associado a diferentes tecnologias, especialmente ao telégrafo. Como afirma Herbert Casson em sua apologética história do telefone, "nenhuma descoberta jamais foi menos acidental" (Casson, 2006, p. 11). Alexandre Graham Bell estudou as leis da fala, os princípios elétricos e as possibilidades práticas durante anos, até que obteve um resultado satisfatório. Também Elisha Gray desenvolveu uma técnica semelhante; a história de como Bell depositou sua patente em 7 de março de 1876, apenas algumas horas antes de Gray, tornou-se famosa já à época dos acontecimentos (Smil, 2005, p. 227-228). Mas a 
história não se esgota nesses dois: em 2002, o Congresso dos Estados Unidos reconheceu que Antonio Meucci, um imigrante italiano, havia registrado um anúncio de invenção para telefone em 1871, e que o processo não teve prosseguimento por falta de recursos financeiros e dificuldades com a língua inglesa ${ }^{1}$.

Mas foi Alexandre Graham Bell quem logrou transformar o telefone num produto comercialmente viável, tendo uma recepção inicial favorável. Graham Bell e seus associados promoveram diversos eventos pelos EUA, procurando demonstrar a eficácia do telefone: "Muitas vezes eles revelavam o aparelho em extravagantes demonstrações, geralmente envolvendo a transmissão de música e discursos de um lugar para uma audiência em outro" (Fischer, 1992, p. 61). Uma das mais famosas, e certamente a de maior significado para o Brasil, ocorreu na Feira do Centenário em Philadelphia, em 1876, comemorando a efeméride da Independência dos Estados Unidos. Ali um dos ilustres visitantes, o imperador do Brasil, D. Pedro II, fez uso do aparelho, ficando muito impressionado (Berthold, 1922, p. 44).

A recepção inicial positiva, entretanto, não foi unânime. Alguns cientistas e meios de comunicação desqualificaram a invenção, indo desde a acusação de fraude à consideração de que o aparelho era inútil, sendo, no máximo, um brinquedo interessante (Casson, 2006, p. 29-30). Superando diversos obstáculos, a empresa fundada por Alexandre Graham Bell e seus sócios conseguiu transformar o telefone num negócio rentável e em franca expansão, por meio do monopólio das patentes e equipamentos e da concessão de franquias e licenças aos interessados. Até a poderosa empresa de telégrafos Western Union passou a comercializar aparelhos telefônicos desenvolvidos porThomas Edison e Elisha Gray, mas perdeu o processo por quebra de patentes para a empresa de Bell em 1879 (Casson, 2006, p. 53-57; Fischer, 1992, p. 37). A vitória contra a gigantesca empresa nacional de telégrafos transformou a imagem da incipiente empresa telefônica:

A Bell Telephone tomou seu lugar junto ao Telégrafo, à Ferrovia, ao Navio a Vapor, à Colheitadeira e às outras necessidades de um país civilizado. [...] Após cinco meses da assinatura do acordo, precisou haver uma reorga-

1 Cf. Congresso dos EUA, 11 jun. 2002. 
nização; e a American Bell Telephone Company foi criada com 6 milhões de dólares de capital. (Casson, 2006, p. 57)

As principais patentes depositadas por Alexandre Graham Bell nos EUA expiraram em 1893, possibilitando o surgimento de várias empresas telefônicas independentes em diversas áreas daquele país (Fischer, 1992, p. 42-43).Também na Europa os negócios ligados à implantação de linhas, aparelhos e à oferta de serviços telefônicos floresceram. Grande parte dessas empresas resultava de iniciativas privadas em nível municipal.

No Brasil, o início da telefonia se deu mesclando a iniciativa privada à estatal. Em 1877, o primeiro telefone foi construído nas oficinas da Western and Brazilian Telegraph Company, no Rio de Janeiro; outra empresa, Rodde \& Cia., estabeleceu uma linha telefônica entre seu escritório e a Bolsa deValores do Rio de Janeiro (Berthold, 1922, p. 51), além de ter começado a fabricar aparelhos telefônicos (Ueda, 1998, p. 20). No mesmo ano D. Pedro II mandou instalar linhas telefônicas ligando o Palácio da Quinta da BoaVista às residências de seus ministros (Fundação Telefônica, 2010, p. 52). Em 1879, os quartéis da Polícia e dos bombeiros da capital foram ligados por telefone, e o governo imperial entregou a primeira concessão para uso comercial do sistema, em 15 de novembro, a um empreendedor estadunidense (Berthold, 1922, p. 44, 51) ${ }^{2}$. Formaram-se outras empresas concessionárias, privadas, que assumiram a instalação e administração de sistemas telefônicos em diversas cidades do país. A pioneira nessa empreitada foi a Telephone Company of Brazil, depois renomeada Companhia Telephonica do Brazil, criada em 1880 por Theodore N.Vail, o homem por trás da transformação da Bell Telephone numa gigante comercial. A empresa obteve concessões para atuar na capital do Império, no ano seguinte (Berthold, 1922, p. 53-54). Outra companhia digna de nota foi a Brazilianische Electricitats-Gessellschaft, formada pela associação da alemã Siemens \& Halske Aktien-Gessellschaft com Alberto Frend \& Cia, a qual assumiu o contrato com o município do Rio de Janeiro em 1897 (Berthold, 1922, p. 59).Também em outras regiões do Brasil, o telefone foi implementado por empresas privadas; em Pelotas (RS), comerciantes, políticos e empresários associaram-se para fundar uma companhia telefônica: "o interesse da elite

2 Não há, porém, registros de que a concessão tenha sido efetivamente implementada. 
local era manter seus privilégios com relação aos projetos inovadores da época. E com o telefone não foi diferente" (Ueda, 1998, p. 51).

Do mesmo modo, a implantação da telefonia em Minas Gerais foi iniciativa de empresas privadas. A primeira cidade mineira a contar com o sistema telefônico foi a rica "Princesa de Minas", Juiz de Fora. Em agosto de 1883, o principal jornal local passou a publicar o anúncio da Companhia Telephonica do Brazil (O Pharol, 27 ago. 1883). Pouco mais de um mês depois, uma notícia saudava a experiência de ligação com a estação de Engenho Novo, na capital imperial:

Juiz de Fora, sempre ao lado de suas irmãs, compartilhará em pouco tempo de mais esse progresso. Parabéns, pois. [...] cremos que a empresa telefônica vem realizar aqui uma ideia de progresso, necessária à vida de qualquer população. (O Pharol, 4 set. 1883)

Apresentada como confirmação do caráter progressista e civilizado da cidade, a instalação do telefone em Juiz de Fora foi, também, motivo de críticas à mentalidade atrasada de alguns proprietários locais, que se recusavam a permitir a instalação de postes telefônicos pelo boato que estes seriam a causa do aumento de relâmpagos registrado nas chuvas de verão daquele ano (Goodwin, 2015, p. 136).

Os anúncios da companhia fluminense apresentavam uma abordagem pragmática, inserindo a nova tecnologia no ambiente socioeconômico da região, como pode ser visto neste exemplo sobre o "emprego do telefone nas fazendas":

Para os SRS. FAZENDEIROS é um melhoramento de incontestável utilidade e mesmo de TRANQUILIDADE. Colocado um aparelho na sua fazenda pode comunicar-se verbalmente com seus empregados para não distrair de outro serviço um fâmulo. Por motivo de moléstia pode chamar um médico imediatamente. No caso de insubordinação por parte do pessoal de sua fazenda, pedir auxílio à estação que ficar mais próxima, e esta por sua vez à autoridade competente. (O Pharol, 29 set. 1883)

O sistema telefônico de Juiz de Fora foi inaugurado em fevereiro de 1884 (Goodwin, 2015, p. 137). Em 1886, na capital provincial, Ouro Preto, o empresário francês R. Joyeux estabeleceu a ligação telefônica entre o Palácio Presidencial e algumas repartições do governo, bem 
como passou a oferecer o serviço a residências particulares (Veiga, 1998, p. 669). Em outras cidades mineiras, o sistema de telefonia também foi implantado por concessão a empresas privadas. Na nova capital que se planejava para Minas Gerais, porém, a história seria outra.

\section{A nova capital de Minas Gerais: uma cidade ordenada}

O fim do século XIX foi momento, no Brasil, da intensificação de discursos sobre o progresso, o desenvolvimento econômico e tecnológico, a equiparação do país com as "nações civilizadas”, notadamente Grã-Bretanha, França e Alemanha, na Europa Ocidental, e Estados Unidos da América. Em Minas Gerais isso não foi diferente, buscando-se construir um ambiente favorável ao "Progresso" e à "Civilização".

Marco simbólico desse movimento, a construção da nova capital do Estado republicano, ao mesmo tempo em que permitia a reinvenção das identidades histórica e tradicional, sinalizava um novo momento para a sociedade mineira, marcado pelo ordenamento planejado, pelo embelezamento, pelo sanitarismo, pelo controle social. $\mathrm{O}$ gigantesco canteiro de obras tornou-se um laboratório e uma vitrine para o avanço da modernidade urbana em Minas Gerais.

A Cidade de Minas, primeira designação da nova capital, representou uma demonstração de força e pujança do Estado sob o regime republicano, e também de seu compromisso com o progresso e a racionalidade cientificista.Tal concepção se revelava nos discursos sobre a cidade, mas, principalmente, na própria concepção e condução de sua materialização:

Concretamente, o urbanismo reduzia os problemas da cidade ao âmbito da aplicação de técnicas e saberes supostamente neutros e divorciados de determinações políticas, ao mesmo tempo em que procurava assumir para si o papel de auxiliar na construção de uma nova ordem pública. Pode-se dizer que a Comissão Construtora teve uma atuação fiel aos "mandamentos" urbanísticos consagrados na Europa. [...] O engenheiro-chefe contava, para tanto, com amplos poderes: além de responsável pelo planejamento e construção da cidade, estava a seu encargo a condução administrativa das obras. (Julião, 1996, p. 55) ${ }^{3}$

3 Para uma discussão sobre a construção da nova capital e seu significado, ver, por exemplo, Dutra (1996), Varia Historia (1997). 
Havia, entre as lideranças mineiras do recém-instalado regime, o desejo de apresentar ao mundo um Estado moderno, comprometido com o progresso. A criação do espaço urbano da capital, ancorada nos princípios urbanísticos compartilhados por pessoas ilustradas de diversas partes do mundo, seria uma excelente - e prática - forma de concretizar esse compromisso. Os ideais de sanitarismo, embelezamento e monumentalidade marcaram as intervenções urbanas na Europa e nos Estados Unidos, ao longo do século XIX, e iluminavam as pretensões daqueles que entendiam ser a Proclamação da República, em 1889, uma oportunidade para refundar a Nação - tanto a brasileira quanto a mineira ${ }^{4}$.

O papel do governo estadual na industrialização mineira foi inextricavelmente entrelaçado com o processo de construção do Estado (em oposição ao papel do Estado na construção da nação). Nos anos 1890 Minas Gerais era, pode-se afirmar, um grupo de regiões frouxamente amarradas por uma demarcação política há muito mantida, mas que ainda não se concretizara. A construção de Belo Horizonte foi originalmente projetada para fomentar a unidade política (bem como a econômica) dessas regiões diversas. (Eakin, 2001, p. 19)

Assim, a Constituição Mineira, promulgada em 15 de junho de 1891, estabeleceu em suas disposições transitórias "a mudança da capital do Estado para um local que, oferecendo as precisas condições higiênicas, se preste à construção de uma grande cidade" (Artigo 13, apud Mello, 1996, p. 37). Foi definido o Arraial de Belo Horizonte como o local da Cidade de Minas.

A escolha do local constituiu-se, afinal, numa obra de equilíbrio político, pela qual os conservadores renitentes foram vencidos sem que, entretanto, a capital fosse deslocada para as zonas economicamente dinâmicas. $\mathrm{O}$ arranjo obtido visava conciliar tradição e modernidade. (Dulci, 1999, p. 40)

Constituiu-se uma Comissão Construtora para dirigir os trabalhos de demolição e a obra de criação da Cidade de Minas, sob o comando do engenheiro Aarão Leal de Carvalho Reis. Paraense de nascimento, sua

4 Para o perfil desse urbanismo oitocentista e sua difusão pelo mundo, ver Ribeiro (1996). Para Minas Gerais como "nação”, ver, por exemplo, Paula (2000). 
formação profissional e intelectual se deu no Rio de Janeiro, onde se graduou em Ciências Físicas e Matemáticas (1873) e em Engenharia Civil (1874). Além de lecionar na própria Escola Politécnica do Rio, onde se formara, teve uma vida pública intensa, ocupando diversos cargos públicos e políticos 5 . Adepto fervoroso do progresso, leitor de autores franceses, entusiasta dos Estados Unidos, Aarão Reis foi o responsável pelo traçado da planta básica e pela definição dos princípios norteadores dos trabalhos da construção da nova capital de Minas Gerais ${ }^{6}$.

A nova capital nasceu, pois, sob a égide de um corpo técnico imbuído de poderes para definir os rumos da cidade tanto em termos do projeto e da obra - planta da cidade, zoneamento urbano, definição dos parâmetros de construção e moradia etc. -, quanto do gerenciamento do cotidiano urbano durante o período de seu mandato.

Otávio Soares Dulci relaciona a mudança de capital a uma ação deliberada por parte do governo estadual, visando ao desenvolvimento mineiro, num processo no qual há "a primazia de fatores políticos sobre fatores de mercado” (Dulci, 1999, p. 23, 26). Para esse autor, a construção da nova capital

foi um projeto decidido e executado na órbita estatal - por razões de Estado, dir-se-ia. Iniciativa eminentemente política, que procurava a modernização de cima para baixo, representou, ao mesmo tempo, uma experiência relativamente ousada, para os padrões da região e da época, de planejamento público. E, neste sentido, afastava-se significativamente da ortodoxia liberal então professada pelos grupos dirigentes, em Minas como em quase todo o país. (Dulci, 1999, p. 41)

Marshall Eakin, em seu estudo sobre a "industrialização de Belo Horizonte", define a variante brasileira do capitalismo, "caracterizada por forte intervenção estatal, apadrinhamento político, clientelismo, redes familiares e uma pronunciada ausência de inovação tecnológica" (Eakin, 2001, p. 3). Especificamente quanto ao processo mineiro, o

5 Para uma listagem completa, ver Salgueiro (1997, p. 27, nota 15).

6 Em 1895, por divergências com o governo do Estado,Aarão Reis deixou a Comissão Construtora, sendo substituído pelo engenheiro mineiro Francisco de Paula Bicalho, que a dirigiu até sua extinção em 1898, após a inauguração da cidade, ocorrida em 12 de dezembro de 1897. Para mais detalhes, ver Barreto (1950, p. 94). 
autor identifica o forte papel da política:"o desenvolvimento econômico não gerou sucesso político, e sim o contrário. O desenvolvimento econômico dependia do sucesso político", o qual era obtido pelas "conexões entre os indivíduos da elite, forjadas através do clientelismo e do parentesco - conexões que integravam, ao invés de separar, políticos, tecnocratas e empresários" (Eakin, 2001, p. 30, 31).

O peso do dirigismo estatal sobre a nova capital mineira iria se refletir na implantação do sistema telefônico da cidade e, posteriormente, em sua administração.

\section{O sistema telefônico da nova capital: 1894-1912}

Em conformidade com o papel diretivo do aparato estatal, o sistema telefônico da nova capital foi pensado, originalmente, para atender às necessidades de funcionamento da Comissão Construtora. $\mathrm{Na}$ ordem de serviço n. 53, expedida a 4 de outubro de 1894, o Engenheiro-Chefe, Aarão Reis, comunicava aos "Srs. Drs. Chefes de serviço" a instalação do serviço telefônico e estabelecia regras e limites para seu uso.

Comunicando a V.S. achar-se instalado o serviço telefônico destinado a pôr em rápida comunicação a qualquer hora do dia ou da noite os escritórios e residências das divisões, entre si, com a Secretaria, o Almoxarifado, a minha residência; e, bem assim, com a Delegacia de Polícia, - dou por muito recomendado que não se permita o uso dos respectivos aparelhos senão para objeto de serviço e em casos urgentes e necessários; e espero que nunca terei motivo para aplicar penas aos empregados que, por abuso intolerável, se utilizarem de tais aparelhos para dirigir gracejos, ou se entretiverem sobre assunto alheio ao serviço desta Comissão. Fica absolutamente vedado o uso dos mesmos aparelhos a quaisquer pessoas estranhas à Comissão. (Acervo da Comissão Construtora da Nova Capital de Minas MHAB 244/CC Da 13/005) ${ }^{7}$

7 O Acervo da Comissão Construtora da Nova Capital de Minas está fisicamente distribuído por três instituições diferentes: APCBH - Arquivo Público da Cidade de Belo Horizonte; APM - Arquivo Público Mineiro; MHAB - Museu Histórico Abílio Barreto. Há um sítio eletrônico que agrega todo o acervo digitalizado, disponível em <http://comissaoconstrutora.pbh.gov.br/>. Em cada citação será incluída, também, a instituição que guarda o documento fisico e seus dados de localização. 
Aarão Reis se caracterizava "por uma curiosidade intelectual ilimitada"; em seus pareceres técnicos e outros escritos, "a profusão e a atualidade das referências citadas, em todos os seus textos, denotam uma erudição sem fronteiras” (Salgueiro, 1997, p. 23, 31). Não espanta, portanto, que sua compreensão da finalidade e do uso do telefone estivesse em sintonia com a visão corrente na terra de origem do equipamento, os Estados Unidos:

Por meio século, a indústria telefônica dependeu basicamente de uma razão para motivar as pessoas a colocar telefones em suas casas: a praticidade. O telefone ajudaria as pessoas a gerenciar melhor os negócios domésticos e a lidar com emergências. [...] Os anúncios de telefone raramente sugeriam estabelecer uma conversa que não fosse de negócios. (Fischer, 1992, p. 75)

Era a mesma ideia presente nos primeiros anúncios do telefone em Juiz de Fora: agilizar as comunicações entre membros da Comissão Construtora e responder a eventuais emergências seriam a razão pragmática, racional, para a instalação da nova tecnologia.

Para atender exclusivamente às necessidades da Comissão, tinha-se montado um serviço telefônico, composto de um centro de 20 linhas do Sistema William, ligando entre si os diversos escritórios e casas de residência dos chefes de divisão, polícia e estações de Minas e General Carneiro. (Barreto, 1995, p. 444)

Mesmo que para uso restrito, a implantação do serviço telefônico demandava seu aparelhamento com aquisição de materiais diversos. As notas fiscais guardadas no acervo local, emitidas em 1896 pela empresa de Eletricidade León Rodde \& Cia., com sede no Rio de Janeiro, trazem imagens de "pilhas Leclanché" e "genuínos telefones", além de anunciar as "Machinas Dynamo Thury" e da Western Electric Company. Há também notas fiscais emitidas em 1897 pela Electro Propaganda A. R. Chaves, que atuava nos ramos da telefonia, eletricidade e telegrafia, também sediada na capital federal. Nessas notas fiscais estão listados diversos itens comprados para a instalação do serviço telefônico da nova capital. Por exemplo, na fatura do Pedido n. 22, de 11 de março de 1896, discriminam-se $10 \mathrm{~km}$ de fio de cobre para linha telefônica ao preço de $3 \$ 600$ o quilômetro, num total de $360 \$ 000 ; 15$ isoladores de porcelana 
de pé virado, com parafusos para postes de madeira, perfazendo $375 \$ 000$. A nota fiscal datada de 26 de maio de 1896 inclui 6 aparelhos telefônicos Bell Black, custando 690\$000, e 2 aparelhos telefônicos Erickson, com custo de $270 \$ 000$. Há ainda alicates para cortar, fios isolados franceses, fios isolados americanos, isoladores com rosca para madeira e tenazes para esticar fios, entre outros apetrechos. Na nota emitida em 30 de março de 1897, há mais 2 aparelhos telefônicos Bell, ao custo individual de $125 \$ 000$, e 2 aparelhos Erickson de mesa, ao custo individual de $150 \$ 000$, além de uma estação de 3 linhas, custando $100 \$ 000$ (Faturas de compras de aparelhos e acessórios para telefonia, Rio de Janeiro, de 18/03/1896 a 30/03/1897, Notação AI.01.02.02 - 139. APCBH) ${ }^{8}$.

Havia também a questão do pessoal para operar o sistema. Em memorando datado de 18 de maio de 1897, o contador férreo reclama ao chefe da Divisão de Viação Férrea e Eletricidade sobre irregularidades no funcionamento do serviço telefônico:

Peço-vos providências para que o Centro Telefônico cumpra o seu dever, esteja de manhã a postos para dar licença aos trens LU1 e LV1, que partem de Minas às $5 \mathrm{~h} 40$ e $5 \mathrm{~h} 30$. (Acervo da Comissão Construtora da Nova Capital de Minas - APCBH 297/AI.01.03.04 - 297)

A implementação do sistema telefônico enfrentou, ainda, dificuldades de ordem financeira. Em carta datada de 6 de agosto de 1897, a casa comercial León Rodde comunicava ao Engenheiro-Chefe da Comissão Construtora:

Não encontramos empregado nenhum que quisesse fazer a instalação telefônica aí por menos de $10 \$ 000$ diários. Como o preço combinado com o nosso sócio, Sr. León Roddé fosse menor, aguardamos a sua resolução a esse respeito e logo que a tivermos recebido mandaremos junto com a pessoa que para aí for todas as notas e desenhos explicativos para o serviço telefônico. Aproveitamos a ocasião para rogar a V. $\mathrm{S}^{\mathrm{a}}$ o favor de nos dizer se recebeu todo o material de seus pedidos.

8 O link para as notas fiscais no sítio eletrônico do Acervo da Comissão Construtora da Nova Capital de Minas atualmente não permite sua visualização, apenas o download dos arquivos, disponível em <http://comissaoconstrutora. pbh.gov.br/exe_dados_documento.php?intCodigoDoc=AI.01.02.02\%20-\%20 139\&strTipo=DOCUMENTO\%20TEXTUAL\#>. Acesso em 20/4/2017. Para este artigo, foram consultados os documentos físicos no APCBH. 
No canto inferior da mesma carta, Aarão Reis anotou sua resposta: "Responda-se que mandarei esticar as linhas e assentar os aparelhos pelo operário eletricista Rufino Coelho, ao qual deverão os Srs. L. R. \& Cia. dar suas explicações e notas" (Acervo da Comissão Construtora da Nova Capital de Minas - APCBH 209/AI.01.03.01 - 209).

Em 25 de novembro de 1897, a menos de um mês da inauguração da nova capital, o secretário da Agricultura encaminhava ao engenheiro-chefe um ofício, pedindo "as devidas providências a fim de que sejam assentados nesta Secretaria os aparelhos telefônicos que vieram de Ouro Preto e ligados à estação central respectiva". No rascunho do registro, encontra-se riscada a observação: "anotando que esta Repartição possui os aparelhos" (Acervo da Comissão Construtora da Nova Capital de Minas - APM 058/AS-119, p. 355).

Com a implantação do sistema telefônico, surgiram pedidos para que o serviço fosse estendido às residências particulares, algumas das quais pertencentes a pessoas de prestígio em Minas Gerais, como, por exemplo, a família de Afonso Pena. Em uma publicação elencando os advogados locais, seu filho, Afonso Pena Filho, aparece listado com o telefone número 1 - possivelmente, herança deixada pelo pai (A Capital, 21 jul. 1913) ${ }^{9}$. Deve-se lembrar, também, que muitos funcionários e representantes políticos vieram transferidos da antiga capital, onde havia o serviço telefônico disponível ${ }^{10}$. Para atender a essas demandas, foram necessários novos investimentos por parte da Comissão Construtora.

A instâncias de muitos particulares que desejavam gozar de semelhante serviço, mediante pagamento de mensalidades, encomendou a Comissão outro centro para 50 linhas, que foi assentado em fins de 1895. O centro telefônico primitivo funcionava em um cômodo anexo ao escritório central da Comissão Construtora, sendo depois transferido para um pequeno prédio de cimento armado que o engenheiro chefe mandara construir por experiência à Rua do Rosário e que hoje ficaria situado entre as ruas Guajajaras, Sergipe, Timbiras e Avenida João Pinheiro. Era encarregado do centro te-

9 Afonso Augusto Moreira Pena foi deputado provincial e geral, ministro e conselheiro do Império; na República, foi senador mineiro, presidente do estado de Minas Gerais e presidente do Brasil. Faleceu durante seu mandato nesse cargo, em 1906. Para uma análise de sua trajetória, ver Lima (2016).

10 Devo aos membros do Grupo de Pesquisa Elementos Materiais da Cultura e Patrimônio (UFMG/CNPq) essa observação. 
lefônico o Sr. Carlos Lynch, que aí permaneceu até depois de mudada a capital. (Barreto, 1995, p. 444) ${ }^{11}$

Esse novo centro telefônico foi incorporado à rotina burocrática da Comissão Construtora. Abílio Barreto coligiu várias informações do "Relatório apresentado pelo Engenheiro-Chefe ao Estado de Minas Gerais", por ocasião do pedido de demissão de Aarão Reis.Ao apresentar o movimento de receita da Comissão Construtora da Nova Capital do Estado de Minas Gerais no período de 22 de fevereiro de 1894 a 31 de dezembro de 1896, o autor incluiu a importância obtida com a instalação de telefones em casas particulares para três meses: em julho, $497 \$ 000$; em setembro, $370 \$ 000$; e, em dezembro, $109 \$ 360$, totalizando $976 \$ 510$. Não há informações quanto ao número de telefones que esses valores representam. Mas, no registro das despesas gerais, lavrado em 30 de janeiro de 1897 , há a anotação de 4:730\$522 destinados a postes telefônicos. No quadro de despesas que o autor elabora "a partir do Relatório do secretário de Agricultura ao Sr. Presidente do Estado e dos créditos votados para a obra da cidade", a despesa com "Telefone" chegou a 16:834\$057, e a receita com o mesmo item acumulou apenas 3:926\$030 (Barreto, 1995, p. 710, 713-14). Fica evidente que não havia preocupação em seguir uma lógica comercial, até porque a primeira finalidade do serviço telefônico na nova capital de Minas era, como exposto, atender às necessidades de funcionamento das instâncias administrativas do governo local e estadual. A expansão do serviço a particulares e a consequente renda adquirida poderiam ser vistos como bônus derivados do intento original.

Mas havia aqueles que enxergavam o potencial mercado que se abria na capital. Em setembro de 1897, R. Joyeux, "eletricista e proprietário da empresa telefônica em Ouro Preto”, solicitou à Câmara dos Depu-

11 A pasta 54(B) - Telefone, no APCBH, contém um manuscrito não identificado, que apresenta esse texto em versão quase igual ao publicado por Abílio Barreto. Nele afirma-se que o "Anuário de Belo Horizonte, ano de 1953" foi a fonte de algumas das informações; e, ao final, é acrescentada a informação relativa à inauguração da capital, "quando aquele serviço foi mudado para a casinha então construída na praça da República (depois Afonso Arinos), atrás da Faculdade de Direito”. O Anuário Historico-Chorographico de Minas Geraes para o ano de 1907 localiza o Centro Telefônico da Capital "no cruzamento da rua Guajajaras [com] avenida Álvares Cabral", o que poderia corresponder à localização proposta no documento citado. 
tados do Estado de Minas Gerais “o privilégio telefônico pelo prazo de 25 anos, sem ônus para o Estado, em Belo Horizonte" ${ }^{12}$. O peticionário oferecia "ao Governo, tão logo se estabeleça a Empresa, 20 por cento de abatimento das condições das assinaturas e de 50 por cento logo que tiver 200 assinantes". E acrescentava:

Não posso oferecer mais vantagens senão a continuação do bom serviço telefônico que a muito custo consegui organizar, sem subvenção alguma, tanto pelo Governo como pelos particulares e a satisfação geral em Ouro Preto. [...] Pois humildemente venho requerer a recompensa do pouco que fiz e do demais que me será possível em bem ao progresso deste tão hospitaleiro Estado de Minas.

A petição foi encaminhada à Comissão Construtora em 17 de setembro de 1897 pelo secretário de Agricultura, Francisco Salles: "referindo-se o pedido à instalação de um serviço na nova capital, vô-lo transmito para que presteis vosso parecer a respeito" (Acervo da Comissão Construtora da Nova Capital de Minas - MHAB 230/CC Da 11/140).

Joyeux não iria receber sua recompensa. Não foi localizado um parecer da Comissão Construtora ou qualquer resposta ao peticionário; talvez o período do pedido, próximo ao encerramento do mandato da Comissão Construtora, ocorrido com a inauguração da nova capital, explique a lacuna. Os desdobramentos posteriores, porém, indicam que seu pleito não obteve sucesso. Em 26 de maio de 1900, foi promulgado o Decreto n. 1383, aprovando "o regulamento para o serviço de eletricidade e telefones da Cidade de Minas". No título III, capítulo VII - Do Serviço Telefônico, o Artigo 37 determinava que "todo o serviço telefônico da cidade de Minas pertence única e exclusivamente à Prefeitura". E estabelecia regras para o funcionamento do sistema telefônico local: quanto aos aparelhos, seu fornecimento e manutenção corriam por conta dos particulares, os quais poderiam, inclusive, realizar a própria ligação, desde que previamente autorizados pela Prefeitura (Artigo 38-40). As instalações cujas taxas mensais fossem pagas adiantadamente receberiam desconto (Artigo 45). Quanto à equipe de

12 Ainda que o nome da capital fosse "Cidade de Minas", sua comarca manteve o nome do arraial, que passou a ser o nome oficial da cidade em 1901 por decisão do Congresso Mineiro (Barreto, 1950, p. 180). 
pessoal, estaria sob a direção do engenheiro auxiliar da Prefeitura, e seria composta por um telefonista, um ajudante, um consertador de aparelhos e um guarda-fios (Artigo 44). A pequena dimensão da equipe conflitava com a responsabilidade prevista no artigo anterior: "haverá sempre, quer de dia, quer de noite, um telefonista no centro telefônico para atender a qualquer chamado" (Collecção das Leis e Decretos do Estado de Minas Gerais, 1899). A falha em atender a esse artigo era motivo de reclamação dos setores que dependiam do serviço telefônico em horários diferenciados. O próprio prefeito responsável pela aplicação do regulamento, Bernardo Pinto Monteiro, reconheceu a necessidade de alterar a organização proposta:

Durante a minha administração verifiquei a impossibilidade de serem os diversos serviços técnicos da cidade dirigidos por um só engenheiro, que, na qualidade de chefe da respectiva diretoria, teria de dar audiências ao público, falar em todos os requerimentos, fiscalizar pessoalmente todos os serviços e confeccionar ainda orçamentos. Tornava-se materialmente impossível serem por ele cumpridos os seus deveres, por isso deliberei, dividir os serviços aludidos em duas diretorias, ficando uma com os serviços de águas, esgotos, canais, eletricidade, telefonia, viação elétrica e conservação de mananciais e a outra com os de obras, construções, arborização, parque, almoxarifado, ruas, lotes, pedreiras, estradas, estatística, veículos, conservação de matas, logradouros públicos e tombamento. (Relatório apresentado ao Conselho Deliberativo pelo Prefeito Dr. Bernardo Pinto Monteiro. 12 de setembro de 1899-31 de agosto de 1902, p. 7) ${ }^{13}$

Como parte da organização administrativa proposta por Bernardo Monteiro, o orçamento aprovado para o exercício de 1901 destinava 5:340\$000 para despesas com o pagamento da equipe do serviço telefônico, reorganizada em sua composição: um encarregado, com vencimento anual de 1:920\$000; um ajudante, recebendo 1:320\$000; um guarda-fios, perfazendo 1:100\$000; e um praticante, a quem se destinavam $900 \$ 000$

13 Os relatórios apresentados pelos prefeitos ao Conselho Deliberativo da nova capital estão sob a guarda do APCBH. Sua versão digitalizada encontra-se disponível em <http://portalpbh.pbh.gov.br/pbh/ecp/comunidade.do?evento=portle t\&pIdPlc $=$ ecp TaxonomiaMenuPortal $\& a p p=$ fundacaocultura \&tax $=6762 \&$ lang $=$ pt_BR \&pg $=5520 \& \operatorname{taxp}=0 \& / \mathrm{pbh} /$ contents.do? evento $=$ conteudo\&lang $=\&$ idCon teudo $=24192 \& \mathrm{chPlc}=24192>$. Acesso em 20/4/2017. 
(Lei n. 4, de 4 de outubro de 1900, Colleç̧ão de Leis do Conselho Deliberativo de Bello Horizonte. De 1900 a 1911: ns. 1 a 53, p. 20 ss.).

Pela documentação localizada, parece que somente em 1910 foi proposta uma solução definitiva para o funcionamento do centro telefônico, com a inclusão no orçamento de uma reforma geral: "o pessoal foi acrescido de quatro (4) senhoras que farão o trabalho diurno e dois empregados que faziam todo o serviço anteriormente trabalharão somente à noite. Por esse modo a rede telefônica funcionará continuamente a qualquer hora do dia ou da noite" (Relatório apresentado ao Conselho Deliberativo com o projeto de orçamento para 1911 pelo Prefeito Dr. Olyntho Meirelles em novembro de 1910, p. 5). A escolha de "senhoras" para operar o centro telefônico segue o padrão estabelecido nos EUA e na Europa, onde mulheres eram consideradas boas opções para o trabalho de telefonista, devido às concepções que vinculavam o sexo feminino à oralidade e ao gosto pela conversa, ainda que isso trouxesse preocupações quanto à sua virtude e curiosidade (Marvin, 1988, p. 26-31) ${ }^{14}$.

$\mathrm{Na}$ linha do comunicado de Aarão Reis citado acima, havia grande preocupação em disciplinar o comportamento dos funcionários em face do telefone. Especialmente quando se tratava do pessoal que atendia ao centro telefônico, já que uma de suas funções era acompanhar a conversa, a fim de garantir que as ligações não fossem interrompidas indevidamente. Assim, o Artigo 41 garantia que apenas a equipe tivesse acesso aos equipamentos, tornando "expressamente proibido o ingresso de pessoas estranhas ao serviço na sala de aparelhos do serviço telefônico". E o Artigo 42 estabelecia claramente que "os empregados do centro telefônico são obrigados a guardar absoluto segredo sobre as conversações havidas nos aparelhos, sob pena de demissão" (Collecção das Leis e Decretos do Estado de Minas Gerais, 1899, p. 346-347). Numa cidade das proporções da nova capital, e com tantos interesses envolvidos no seu cotidiano, o acesso a conversas particulares ou de negócios, principalmente, era um assunto a ser tratado com seriedade.

O funcionamento do sistema telefônico apresentou diversos problemas, tanto técnicos quanto operacionais. Um dos principais desafios era

14 Claude Fischer argumenta que as mulheres foram as grandes responsáveis pelas mudanças no uso social do telefone, de aparelho eminentemente prático a meio de sociabilidade (Fischer, 1992, p. 235). 
a estrutura física necessária à extensão do sistema pela cidade, pela precariedade dos postes e pelos problemas práticos referentes à instalação dos fios. Em outras palavras, a materialização das linhas do progresso. O prefeito Bernardo Pinto Monteiro teve que enfrentar também essa questão:

Procurei dar grande desenvolvimento à linha telefônica, que em uma cidade, como esta, de distâncias enormíssimas, constitui uma necessidade imprescindível. De 29 elevei o seu número de aparelhos a 97, para o que foram assentados 100 quilômetros de linha, e substituídos postes de madeira por outros de trilhos. As linhas ressentem-se de pequenos defeitos, que serão, com vagar, corrigidos. Atendendo à afluência de assinantes, preciso adquirir um novo centro, que deve custar cerca de 4:000\$000. (Mensagem ao Conselho Deliberativo da Cidade de Minas.Apresentada em 19 de setembro de 1900 pelo Prefeito Dr. Bernardo Pinto Monteiro, p. 31)

Característica constante desse processo é a necessidade de aquisição de novos centros telefônicos que permitissem a conexão de um maior número de linhas. O primeiro, instalado pela Comissão Construtora, tinha o limite de 20; como visto, a oferta do serviço a particulares exigiu a encomenda de outro, com capacidade para mais 50. Os centros telefônicos serão constantemente substituídos, visando à ampliação da oferta de linhas, como mostram os relatórios da $2^{2}$ Diretoria de Obras apresentados pelos prefeitos ao Conselho Deliberativo em 1903, 1906, 1908, 1910 e 1912.

Bernardo Pinto Monteiro referiu-se aos "pequenos defeitos" nas linhas telefônicas. No relatório em que fez um balanço geral de sua administração, de 1899 a 1902, ele ofereceu mais detalhes desses problemas, que geravam

a interrupção do serviço de telefones, motivada pelas más condições em que se achavam as suas linhas. Instaladas provisoriamente pela Comissão Construtora, em postes baixos, e aumentando-se dia a dia em número, essas linhas apresentavam ultimamente contatos com os fios da luz, podendo esse fato dar lugar a sérios desastres. No correr do ano só uma vez tivemos interrompida a iluminação, por algumas horas, e isto mesmo devido a contato com as linhas telefônicas. (Relatório apresentado ao Conselho Deliberativo pelo Prefeito Dr. Bernardo Pinto Monteiro. 12 de setembro de 1899-31 de agosto de 1902, p. 111) 
$\mathrm{O}$ relatório aventa o risco de acidentes devido à proximidade dos fios telefônicos e elétricos. Risco que havia se concretizado em meados daquele ano de 1902, com o incêndio ocorrido no Centro Telefônico:

Estendidas essas linhas, em grande número sobre postes baixos e flexíveis, davam incessante trabalho para sua manutenção, devendo guardar a necessária distância dos cabos de luz e ultimamente de bondes. Não era mesmo dificil se desse algum desagradável acidente, porquanto os frequentes contatos poderiam determinar a morte de qualquer indivíduo que tocasse num aparelho. Felizmente, em lugar de caso tão desagradável, o último contato determinou um começo de incêndio, na estação central, inflamando as substâncias isolantes de uma série de fios. $\mathrm{O}$ incêndio foi prontamente abafado e, por deliberação vossa [do prefeito], foi desde logo suspenso o serviço, para ser de novo instalado, com a brevidade possível, mas com segurança e garantia precisas. Aproveitada a oportunidade para a alteração e melhor disposição dos aparelhos na estação central, estão já instalados e, dentro em breve, serão estendidas as linhas, não em postes bastante altos, como desejávamos, mas em postes adquiridos da E. de F. Central e outros de que poderemos aqui dispor, que serão adaptados e modificados, de modo a satisfazerem as necessidades. (Relatório apresentado ao Conselho Deliberativo pelo Prefeito Dr. Bernardo Pinto Monteiro. 12 de setembro de 1899-31 de agosto de 1902, p. 126)

Enfrentando a crise como uma oportunidade, a Diretoria responsável pelos serviços telefônicos propunha-se a reorganizar toda a disposição dos equipamentos e os postes que sustentavam as linhas telefônicas. Não obstante, foi obrigada a reconhecer o efeito devastador do incêndio sobre o funcionamento do sistema na cidade: "atualmente funcionam apenas 20 linhas, ligadas aos edifícios públicos, que não apresentam os mesmos perigos, porque são poucas e distribuídas por diversas ruas". Antes do incêndio, eram 117 os aparelhos em funcionamento, e 57 haviam sido instalados recentemente (Relatório apresentado ao Conselho Deliberativo pelo Prefeito Dr. Bernardo Pinto Monteiro. 12 de setembro de 1899-31 de agosto de 1902, p. 127). O progresso, na nova capital de Minas, avançava por linhas tortas e fios embaralhados.

Outro obstáculo ao bom funcionamento do sistema era a própria qualidade dos aparelhos telefônicos utilizados, como relatou o Prefeito Benjamim Jacob: 
Têm sido rigorosamente fiscalizadas as novas instalações de telefones, a fim de impedir a introdução de aparelhos ordinários na rede. Pelo sistema adotado pela Prefeitura, sistema, aliás, condenável, o aparelho é fornecido pelo assinante, e daí a tendência de instalar aparelhos usados, algumas vezes imprestáveis. (Relatório apresentado ao Conselho Deliberativo pelo Prefeito Benjamim Jacob em 16 de setembro de 1908, p. 61-62)

Se não bastassem as deficiências próprias do sistema telefônico, o desenvolvimento da cidade trouxe ainda outros desafios:

O funcionamento do serviço telefônico não é ainda irrepreensível, pois, frequentemente, se nota que o empregado da central não atende ao sinal de chamada; este fato, que ocorreu depois da inauguração do serviço de bondes, é atribuído a um desvio da corrente de retorno pelas más condições de condutibilidade dos trilhos, indo a corrente pelo solo pegar as linhas de terra dos aparelhos do centro, determinando a queda dos drops ${ }^{15}$. Esse defeito desaparecerá brevemente, pois vão ser melhoradas as ligações dos trilhos, que deverão ser reparados ou substituídos todos, dispensando talvez a duplicidade das linhas telefônicas. (Relatório apresentado ao Conselho Deliberativo pelo Prefeito Francisco Bressane de Azevedo em 16 de setembro de 1903, p. 35-36)

Apesar do otimismo expresso no relatório, o problema persistiu por muitos anos. Em 1905 o mesmo prefeito informou sobre a instalação de um novo quadro no centro telefônico, bem como a substituição de parte dos equipamentos das linhas de transmissão elétrica dos bondes, gerando melhorias no sistema telefônico da cidade. Mas não resolveu todos os problemas.

São mais frequentes, porém, as interrupções em épocas de trovoadas e isto porque sendo esse quadro mais apropriado para linhas duplas, de retorno metálico e tendo as bobinas dos drops ligadas à terra, constituídas de um fio extremamente fino, tornam-se essas bobinas de extrema sensibilidade às descargas atmosféricas. De tal modo, que nem os fusíveis de papel dourado empregados, podem evitar que se queimem com insignificante

15 O drops, nesse caso, refere-se aos cabos e fios que realizavam a ligação entre a fiação nos postes e o Centro Telefônico, conforme está disponível em <https://en.wikipedia. org/wiki/Drop_\%28telecommunication\%29>. 
trovoada, deixando o assinante desde logo isolado do Centro. Esse inconveniente, porém, tem sido corrigido, empregando-se no enrolamento dessas bobinas um fio mais grosso e à medida que esse vai sendo feito, são colhidos benéficos resultados. (Relatório apresentado ao Conselho Deliberativo pelo Prefeito Francisco Bressane de Azevedo em setembro de 1905, p. 44-45)

A questão do sistema de condução e isolamento elétrico teve outros impactos, "fazendo-se necessária a substituição do Centro Erickson, atualmente em serviço, por não se prestar ao sistema de retorno da corrente por terra, foi encomendado um Centro Kellog, que satisfaz essa exigência" (Relatório apresentado ao Conselho Deliberativo da Cidade de Belo Horizonte pelo Prefeito Interino Dr.Antonio Carlos Ribeiro de Andrada em setembro de 1906, p. 27). No ano seguinte os conflitos entre a fiação telefônica e o fornecimento de energia aos bondes continuaram a atormentar a Diretoria responsável:

O serviço de telefones ressente-se do sistema adotado de linha com volta de terra, o que absolutamente não é recomendável em lugares onde há viação elétrica usando também volta de terra. Pretendo estabelecer retorno metálico comum, quando fizer a instalação da rede em postes separados, o que melhorará consideravelmente o serviço. (Relatório apresentado ao Conselho Deliberativo pelo Prefeito Benjamim Jacob em 23 de setembro de 1907, p. 51)

Apenas em 1909 foram instalados postes de 15 metros de altura, "destinados à separação das redes de telefones das redes de luz e bondes, dependendo o início do serviço da chegada de materiais encomendados" (Relatório apresentado ao Conselho Deliberativo pelo Prefeito Benjamin Brandão em janeiro de 1910, dispõe sobre assumptos referentes ao ano decorrido de agosto de 1908 a setembro de 1909, p. 44). E, em 1911, foi resolvido o problema dos drops:

Sofreram uma reforma completa, tanto o edificio onde funciona o Centro, como os aparelhos centrais e linhas. Na torre, onde se fez a entrada destas, estão colocados fusíveis protetores para correntes de alta tensão e para-raios, em cada uma das linhas. (Relatório apresentado ao Conselho Deliberativo com o projeto de orçamento para 1911 pelo Prefeito Dr. Olyntho Deodato dos Reis Meirelles, p. 49) 
Apesar dos constantes problemas de pessoal, de equipamento e de instalação e conflitos com o fornecimento de energia elétrica, o sistema telefônico da nova capital mineira vivenciou um processo de expansão quase permanente. A partir das informações disponíveis em diferentes documentos, foi elaborado o quadro abaixo, mostrando o número de telefones em funcionamento na nova capital por ano, bem como algumas informações relativas à ampliação e ao melhoramento do sistema. Para efeito de comparação, são apresentados alguns dados disponíveis sobre o sistema telefônico na capital federal, para o período de 1906 a 1912.

\begin{tabular}{|c|c|c|c|c|}
\hline \multicolumn{5}{|c|}{ Quadro 1 - Expansão do sistema telefônico na nova capital, 1895-1912 } \\
\hline \multirow[t]{2}{*}{ ANO } & \multirow{2}{*}{$\begin{array}{c}\text { NÚMERO } \\
\text { DE } \\
\text { TELEFONES }\end{array}$} & \multirow[t]{2}{*}{ OBSERVAĈ̣̃o } & \multicolumn{2}{|c|}{ Rio DE JANEIRO } \\
\hline & & & \begin{tabular}{|c} 
NúMERO \\
DE \\
TELEFONES
\end{tabular} & $\begin{array}{c}\text { KM } \\
\text { LINHAS }\end{array}$ \\
\hline 1895 & 20 & Novo centro encomendado para mais 50 conexões. & - & - \\
\hline 1899 & 29 & & - & - \\
\hline 1900 & 97 & $\begin{array}{l}100 \mathrm{~km} \text { de linhas; compra de novo centro } \\
\text { telefônico. }\end{array}$ & - & - \\
\hline \multirow[t]{2}{*}{1902} & 117 & Antes do incêndio no centro telefônico (julho). & - & - \\
\hline & 20 & Após o incêndio no centro telefônico (agosto). & - & - \\
\hline 1903 & 120 & $\begin{array}{l}\text { Novo quadro encomendado para mais } 200 \\
\text { conexões. }\end{array}$ & - & - \\
\hline 1905 & 126 & & - & - \\
\hline 1906 & 126 & $\begin{array}{l}\text { Ligação com mina de Morro Velho; substituição do } \\
\text { Centro Erickson por um Kellog, encomendado. }\end{array}$ & 2.000 & - \\
\hline 1907 & 125 & Mais 27 telefones, da Prefeitura e gratuitos. & 2.680 & - \\
\hline 1908 & 178 & $\begin{array}{l}102 \text { particulares, } 51 \text { do Estado, } 21 \text { da Prefeitura e } 4 \\
\text { gratuitos. }\end{array}$ & 3.520 & - \\
\hline 1909 & 249 & Instalação dos postes de $15 \mathrm{~m}$ separando fiações. & 3.991 & - \\
\hline 1910 & & $198 \mathrm{~km}$ de linhas telefônicas. & 4.859 & 25.000 \\
\hline 1911 & 400 & $657 \mathrm{~km}$ de linhas telefônicas. & 6.275 & 32.000 \\
\hline 1912 & 500 & $\begin{array}{l}\text { Novo quadro encomendado para mais } 500 \\
\text { conexões. }\end{array}$ & 9.020 & 42.000 \\
\hline
\end{tabular}

Fontes: Anuário Historico-Chorographico de Minas Geraes (1906-1918), Barreto (1995), Berthold (1922), Relatórios de prefeitos ao Conselho Deliberativo (1900-1912).

O caráter lacunar das informações é problema antigo. Quando escreveu sua história do telefone e do telégrafo no Brasil para a American Telegraph \& Telephone Company, em 1921,Victor Maximilian Berthold fez questão de comentá-lo: 
Que o Governo de um país, ocupando tal posição de liderança no comércio mundial, tenha aparentemente ignorado a importância de possuir informações estatísticas acuradas e atualizadas sobre um dos seus serviços públicos mais importantes, é lamentável. (Berthold, 1922, p. 69)

Em praticamente todos os relatórios de prefeitos ao Conselho Deliberativo, que incorporavam os relatórios da 2a Diretoria de Obras, responsável pelo serviço telefônico, é feita menção à situação deste. Todavia, não havia uma padronização quanto às informações a serem apresentadas nem uma preocupação em sistematizar os dados relativos ao sistema telefônico na nova capital mineira. Assim, no conjunto dos relatórios há a apresentação de dados numéricos quanto ao número de novas instalações e desligamentos; ao tipo de ligação realizada, se particular ou pública; ao número de aparelhos consertados; ao número total de telefones em operação; à quilometragem das linhas telefônicas; à capacidade dos quadros do centro telefônico; e ao funcionamento das linhas telefônicas. Entretanto, nenhum dos relatórios apresenta todas essas informações em conjunto. O quadro acima é uma composição de diversas informações obtidas em documentos diferentes, principalmente os relatórios dos prefeitos, mas também os anuários históricos produzidos por Nelson Coelho de Senna para os anos de 1906, 1907, 1909, 1911, 1913 e $1918^{16}$. As informações relativas ao Rio de Janeiro foram retiradas da obra que Berthold produziu sob os auspícios da companhia telefônica dos EUA.

A comparação com a capital federal, aliás, coloca em perspectiva o acanhado desenvolvimento do sistema telefônico da nova capital mineira. Dez anos após o início das operações no canteiro de obras da então Cidade de Minas, o total de telefones instalados não chegava a $10 \%$ do número de aparelhos em funcionamento no Rio de Janeiro. Ainda que se considere a diferença de população e o maior tempo transcorrido desde a implantação do telefone naquela cidade - como visto acima, em 1877 -, a defasagem é enorme. Em favor do Rio de Janeiro, pesam diversos fatores, não sendo o menor deles o seu status

16 Nelson Coelho de Senna graduou-se em direito e atuou como jornalista e professor de história e da Faculdade de Engenharia. Membro da Academia Mineira de Letras, publicou, além da série de anuários, outras obras de história, entre elas O Cinquentenário de Belo Horizonte (Martins Filho, 2013, p. 448). 
de capital nacional, grande vitrine das realizações de progresso do Império e da República, talvez o maior "sinal visível de civilização" que o país tinha a oferecer - não obstante todas as contradições, incoerências e incompletudes que compunham aquela cidade. Embora possa ser considerada injusta sob certos aspectos, a comparação serve para mostrar a tibieza do sistema telefônico da capital mineira, apesar dos discursos que o relacionavam ao progresso e ao desenvolvimento técnico e o caracterizavam como "uma necessidade imprescindível" para a comunicação na cidade.

Mesmo no campo do discurso, o telefone aparece em desvantagem. A leitura da documentação produzida pela Prefeitura, e também das peças de orçamento aprovadas pelo Conselho Deliberativo, demonstram que o serviço telefônico sempre esteve em plano secundário, quando comparado aos serviços de fornecimento de energia elétrica e às questões relativas ao abastecimento e escoamento das águas urbanas. $\mathrm{O}$ serviço telefônico gerava menos receita que o serviço de eletricidade, o que pode ter justificado a aprovação da proposta de orçamento para o exercício de 1905, formalizada na Lei n. 15, de 1ํo de outubro de 1904, a partir da qual as taxas de luz e telefone foram unificadas na previsão de rendas e de despesas (Collecção de Leis do Conselho Deliberativo de Bello Horizonte. De 1900 a 1911:ns. 1 a 53, p. 52). Como exemplo da discrepância entre as rendas obtidas pelos serviços, a Lei n. 12, de 8 de outubro de 1903, que aprovou o orçamento da capital para o exercício de 1904, previa em seu Artigo 1으 parágrafo 8o, taxas do serviço de telefone, a renda de 2:000 $\$ 000$; o parágrafo anterior, referente às taxas do serviço de eletricidade, previa a renda de 60:000\$000 (Collecção de Leis do Conselho Deliberativo de Bello Horizonte. De 1900 a 1911: ns. 1 a 53, p. 39). Logo, é razoável supor que a renda prevista no orçamento para 1905 das taxas "de luz e telefone", no valor de 65:000\$000, seria composta majoritariamente pela cobrança do serviço de energia elétrica.Além de demonstrar o caráter minoritário do serviço telefônico na composição de receita da Prefeitura Municipal, o registro unificado dificulta o trabalho do historiador quanto à expectativa de renda e às despesas específicas do serviço telefônico.

A previsão orçamentária para os dois serviços permaneceu sob a mesma rubrica até que o Prefeito Benjamim Jacob ponderou, no parágrafo $8^{\circ}$ do Artigo 1ํㅡㄹ sobre sua proposta de orçamento para o exercício 
de 1908, que "têm sido incluídas estas taxas no parágrafo acima [taxas de luz elétrica], convindo destacá-las" (Relatório apresentado ao Conselho Deliberativo pelo Prefeito Benjamim Jacob em 23 de setembro de 1907, p. 85). O mesmo prefeito, todavia, renomeou a $2^{\underline{a}}$ Diretoria de Obras, passando a se chamar "Diretoria de Eletricidade", como consta em seu relatório. Embora as previsões de despesa discriminassem os gastos com aquisição de materiais para o serviço telefônico (para 1908, por exemplo, orçadas em 3:000\$000), manteve-se a prática, iniciada em 1905, de não mais listar separadamente os vencimentos da equipe responsável pelo seu funcionamento.

Ainda assim, o telefone era apresentado como parte dos "sinais visíveis de civilização", artefato tecnológico que agilizava a comunicação e facilitava o trabalho. Essa concepção está presente em alguns textos visivelmente imbuídos da proposta de exaltar e louvar o progresso e o desenvolvimento da nova capital de Minas Gerais, como os anuários publicados por Nelson Senna, que incluíam o telefone na lista dos atributos modernos da nova cidade:

Imprensa diária, revista de direito, arte e letras, serviço de assistência pública e hospitalar, telégrafo, telefones, teatro, clubs, asilos, colégios, sociedades pias e beneficentes, de sport (tiro e corridas), institutos leigos e religiosos, templos católicos e protestantes, bibliotecas, hotéis, açougues, policiamento, quartéis, prisões etc., são outros tantos elementos de progresso, que já possui a moderna Capital Mineira. (Senna, 1909, p. 247)

Em praticamente todas as edições localizadas, há alguma menção ao estado do sistema telefônico na capital mineira ou no estado de Minas Gerais. A exceção é o anuário de 1913, talvez pela mudança na administração do sistema; apesar disso, é o primeiro a incluir no expediente o número telefônico da redação: 111 (Senna, 1913, quarta capa).

Apesar desse e de outros discursos que caracterizavam o telefone como parte do "conforto moderno" (Senna, 1918, p. 377) ${ }^{17}$, a depender da leitura de alguns relatórios, poder-se-ia concluir que o telefone era visto, ao menos por alguns administradores, como um estorvo. Em sua

17 O texto do anuário reproduz a síntese produzida por Nelson Senna, utilizada como introdução ao Relatório da Secretaria do Interior do Estado, de 1913, e que fora publicada na primeira página do Jornal do Commercio da capital federal, naquele ano. 
proposta de orçamento para o exercício de 1906, o Prefeito Francisco Bressane de Azevedo reclama da baixa arrecadação das taxas referentes ao serviço de "luz elétrica e telefones":

Este ano já se arrecadou a soma de 40:631 $\$ 973$, faltando arrecadar, mais ou menos, 49:961 $\$ 300$, o que equivale dizer que o lançamento é de 90:593 $\$ 273$, sendo o orçamento computado em 65:000 $\$ 000$. Pelos dados constantes desta exposição, vê-se que a renda deste parágrafo, é que tem tido menos arrecadação. Enquanto que as rendas dos seis parágrafos enumerados atrás [no orçamento], deixam uma porcentagem de 35\% dos lançamentos, para serem arrecadados, esta renda não se mostra recolhida à Tesouraria da Prefeitura na metade sequer do lançamento. Mais de 55\% estão ainda por ser arrecadados, devido, talvez, a não serem sujeitos a multa os contribuintes em atraso de pagamento dessa taxa, por mais atrasados que estejam, sendo a penalidade regulamentar a desligação da luz e cobrança executiva. Parece evidente a necessidade de se impor multa ao contribuinte de luz e telefone que não observe as prescrições regulamentares relativas ao pagamento dessas taxas. (Relatório apresentado ao Conselho Deliberativo pelo Prefeito Francisco Bressane de Azevedo em setembro de 1905, p. 138)

Alguns anos depois, o Prefeito Benjamim Jacob apresentou outra razão para o baixo retorno aos cofres públicos do serviço telefônico: o pequeno valor cobrado aos assinantes pelo uso do sistema, ocasionando prejuízo financeiro à municipalidade, responsável pelo seu funcionamento.

O serviço de telefones traz à Prefeitura um prejuízo médio mensal de $5[9] 0 \$ 000$, motivado pela taxa extraordinariamente baixa, sem paralelo em parte alguma, de $60 \$ 000$ anuais. Realmente, no Rio, onde o serviço não é melhor do que o nosso, são estas as taxas:

$\begin{array}{lll}1^{\circ} & \text { Perímetro } & 170 \$ 000 \\ 2^{\circ} & \text { Perímetro } & 240 \$ 000 \\ 3^{\circ} & \text { Perímetro } & 300 \$ 000\end{array}$

$\mathrm{O} 1^{\circ}$ perímetro é limitado pela Praia de Botafogo e rua Haddock Lobo (fim). O segundo vai até S. Francisco Xavier, e o $3^{\circ}$ até Engenho de Dentro. S. Paulo tem também 3 taxas dependendo da distância ao Centro Telefônico: são elas $160 \$ 000,200 \$ 000$ e $240 \$ 000$. Para equilibrar a despesa torna-se 
necessário elevar a taxa a $120 \$ 000$, o que não será exagerado. (Relatório apresentado ao Conselho Deliberativo pelo Prefeito Benjamim Jacob em 23 de setembro de 1907, p. 51)

O Quadro 1 revela que, naquele ano, o Rio de Janeiro possuía 2.680 aparelhos em funcionamento, contra os 125 assinantes pagos de Belo Horizonte, mais os 27 aparelhos instalados para o serviço da Prefeitura e outros subsidiados por ela. A diferença na arrecadação deveria ser, realmente, volumosa; o baixo número de assinantes, se fossem seguidas as regras do mercado, implicaria uma taxa mais alta na capital mineira que na federal. A comparação com São Paulo apenas agravava a discrepância, pois sugeria que a capital mineira não acompanhava o que havia de mais moderno em gestão e administração de serviços técnicos. Como solução para esse problema, o prefeito apresentou a seguinte consideração:

Reportando-me ao que ficou exposto sobre este serviço, na parte relativa à Diretoria de Eletricidade, proponho-vos que a taxa de telefone seja elevada a $120 \$ 000$ por ano, como era antigamente. (Relatório apresentado ao Conselho Deliberativo pelo Prefeito Benjamim Jacob em 23 de setembro de 1907, p. 72)

Benjamim Jacob referia-se ao valor estabelecido pelo Decreto n. 1211, de 31 de outubro de 1898, que promulgou as Posturas da Cidade de Minas. Em seu Artigo 26 ficava estabelecida a taxa de $10 \$ 000$ mensais para cada aparelho telefônico (Colleç̧ão das Leis e Decretos do Estado de Minas Gerais, 1898, p. 245). Não foi localizado o documento que alterou esse valor; todavia, a Lei n. 1, de 25 de janeiro de 1900, que aprovou o orçamento da Cidade de Minas para o exercício daquele ano, estabelecia em seu Artigo 3o, inciso III: “É elevada a $60 \$ 000$ anuais a taxa de serviço telefônico" (Collecção de Leis do Conselho Deliberativo de Bello Horizonte. De 1900 a 1911: ns. 1 a 53, p. 4). Esse valor foi mantido em todas as propostas de orçamento seguintes, até que Benjamim Jacob sugeriu alterá-lo. Ao justificar sua proposta de orçamento para o exercício de 1908, reforçou o argumento:

Como já tive ocasião de vos ponderar, a taxa desse serviço deve ser elevada a $10 \$ 00$ mensais, sob pena de dar grande prejuízo à Prefeitura. Entrando com esta taxa, a renda será de 12:500\$00, digamos 12:000\$000. 
(Relatório apresentado ao Conselho Deliberativo pelo Prefeito Benjamim Jacob em 23 de setembro de 1907, p. 85)

No projeto apresentado ao Conselho Deliberativo, o prefeito incluía o "Art. $3^{\circ}$. Fica elevada a $10 \$ 000$ mensais a taxa do serviço de telefones" (Relatório apresentado ao Conselho Deliberativo pelo Prefeito Benjamim Jacob em 23 de setembro de 1907, p. 89). No orçamento para o exercício de 1908, aprovado pela Lei n. 25, de 16 de outubro de 1907, foi incorporado o valor proposto pelo prefeito para a renda das taxas do serviço de telefone, de 12:000\$000, que passou a ser registrado em parágrafo próprio, como visto acima. Todavia, o aumento da taxa de serviço telefônico não constou da lei orçamentária (Colleç̧ão de Leis do Conselho Deliberativo de Bello Horizonte. De 1900 a 1911: ns. 1 a 53, p. 58). Na mesma data foi aprovada a Lei n. 26, específica sobre taxas de serviço, a qual estabeleceu em seu Artigo 6: "continuam em vigor as tabelas de impostos e taxas de serviços estabelecidas nas leis e regulamentos da Prefeitura, salvo as alterações feitas nesta lei". A taxa de serviço telefônico não é mencionada no texto (Colleç̧ão de Leis do Conselho Deliberativo de Bello Horizonte. De 1900 a 1911: ns. 1 a 53, p. 60). Ou seja: aprovou-se o aumento da expectativa de renda sem se aprovar o aumento da taxa a ser cobrada, que garantiria a realização do orçamento aprovado.

Benjamim Jacob voltaria à carga em seu relatório referente ao ano de 1908. Ao comentar o serviço telefônico, além da já citada crítica à permissão para que os assinantes fornecessem os próprios aparelhos para instalação, o prefeito retomou a questão financeira:

O serviço telefônico continua a trazer prejuízos à Prefeitura, devido à pequena taxa estabelecida que, como fiz ver em meu relatório de 1907, não tem igual em parte alguma. Enquanto em Belo Horizonte a taxa anual uniforme é de $60 \$ 000$, no Rio a taxa varia de $170 \$ 000$ a $300 \$ 000$ e em S. Paulo de $160 \$ 000$ a $240 \$ 000$, conforme as distâncias do Centro. (Relatório apresentado ao Conselho Deliberativo pelo Prefeito Benjamim Jacob em 16 de setembro de 1908, p. 61)

Sua preocupação gerou um dos relatórios mais detalhados quanto ao número e ao uso dos telefones instalados na cidade. De acordo com o prefeito, o sistema telefônico da nova capital compreendia 102 telefones particulares, 51 telefones do Estado, 21 telefones da Prefeitura e 4 tele- 
fones gratuitos: da Santa Casa, da residência do Provedor, da estação da Estrada de Ferro Central e da Companhia Morro Velho de mineração, totalizando 178 telefones. Desses dados, conclui que "a renda anual deste serviço deverá ser, portanto, em 1908, mais ou menos, de 9:180\$000, ou, como já afirmamos no presente relatório, não atingirá a previsão orçamentária, que é de 12:000\$000" (Relatório apresentado ao Conselho Deliberativo pelo Prefeito Benjamim Jacob em 16 de setembro de 1908, p. 78). Ao baixo valor da taxa de serviço acrescentava-se a má arrecadação desta: "a dívida ativa de luz e telefones parece-me de muito má liquidação, não assim as demais que mesmo os srs. agentes-fiscais, devidamente instruídos, vão arrecadando paulatinamente" (Relatório apresentado ao Conselho Deliberativo pelo Prefeito Benjamim Jacob em 16 de setembro de 1908 , p. 83). Para solucionar o problema, o prefeito retomou a proposta do ano anterior:

Durante o ano corrente, com um orçamento de 12:000\$000, tivemos, no semestre vencido, uma arrecadação de 5:475\$. A minha proposta de 12:000 $\$ 000$, do ano passado, supunha a elevação da taxa de $5 \$ 000$ a $10 \$ 000$ mensais. O número de ligações elevou-se um pouco, de sorte que, elevada a taxa a $10 \$ 000$ por mês, para não dar o serviço prejuízo à Prefeitura, pode-se tomar para previsão orçamentária do futuro exercício, o algarismo de 12:000\$000. (Relatório apresentado ao Conselho Deliberativo pelo Prefeito Benjamim Jacob em 16 de setembro de 1908, p. 101)

O Conselho Deliberativo optou pelo caminho inverso: ao invés de aumentar a taxa mensal do serviço telefônico, optou por reduzir pela metade a expectativa de renda deste para o exercício de 1909: 6:000\$000 (Collecção de Leis do Conselho Deliberativo de Bello Horizonte. De 1900 a 1911: ns. 1 a 53, p. 64). Além da redução de renda, a despesa com material telefônico passou dos 3:000\$000 orçados, nos exercícios de 1908 e 1909, para 5:000\$000, no orçamento do exercício de 1910 (cf. Lei n. 25, de 16 de outubro de 1907, e Lei n. 30, de 7 de outubro de 1908 (Colleç̧ão de Leis do Conselho Deliberativo de Bello Horizonte. De 1900 a 1911: ns. 1 a 53, p. 58, 64) ${ }^{18}$. Diante da despesa crescente, o Prefeito Olyntho

18 Em 1910, a despesa com "Materiais para o serviço telefônico" chegou à cifra de $38: 377 \$ 525$, para uma verba orçada em 30:000\$000; do orçamento de 13:500 $\$ 000$, a arrecadação de taxas chegou a 12:921\$000 (Relatório apresentado ao Conselho 
Meirelles buscou uma forma alternativa de tentar diminuir o prejuízo que o sistema telefônico representava, em tempo e dinheiro, para a administração municipal:

A contribuição de mil réis $(1 \$ 000)$ mensais para a conservação e conserto dos telefones, além de ser uma quantia insignificante, simplificará sobremodo a escrituração e arrecadação desse serviço executado pelos empregados da Prefeitura. // Tal conserto requerido ou pedido verbalmente pelo assinante custa-lhe sempre quantia inferior a três mil réis ( $3 \$ 000)$; esta, para ser arrecadada, passa, antes, por diversos informes prévios e, quando o empregado vai cobrá-la, não raro, o proprietário do aparelho está ausente, sendo necessário ir a sua casa, uma e mais vezes, para receber quantia tão pequena. (Relatório apresentado ao Conselho Deliberativo com o projeto de orçamento para 1911 pelo Prefeito Dr. Olyntho Meirelles em novembro de 1910, p. 5)

Essa estratégia, embora não resolvesse completamente a questão, foi bem-sucedida. A Lei n. 45, de 22 de novembro de 1910, que aprovou o orçamento da capital para o exercício de 1911, previa em seu Artigo 5: "para conservação e conserto de aparelhos telefônicos a cargo da Prefeitura, cobrar-se-á mais um mil réis de cada assinante no ato do pagamento da taxa mensal" (Collecção de Leis do Conselho Deliberativo de Bello Horizonte. De 1900 a 1911: ns. 1 a 53, p. 83).

A discussão sobre a tarifa do serviço telefônico revela dois aspectos importantes do seu funcionamento na capital mineira. $\mathrm{O}$ primeiro, e mais óbvio, é o constante descompasso entre a renda propiciada à administração municipal e as despesas decorrentes da manutenção e gestão do sistema telefônico, certamente um dos elementos a explicar a baixa prioridade dada ao sistema telefônico, quando comparado com os serviços de eletricidade e águas e esgotos, para ficar dentro das atribuições da mesma Diretoria. Diferença materializada nas rubricas orçamentárias e, mesmo, no número de páginas destinadas a cada item nos relatórios dos prefeitos. Tal situação pode ser explicada, ao menos em parte, pela própria evolução do sistema telefônico: pensado originalmente para suprir funções administrativas do governo municipal, a rede foi ampliada para atender a clientes particulares. Teve que incorporar, assim, as de-

Deliberativo pelo Prefeito Dr. Olyntho Deodato dos Reis Meirelles em 16 de setembro de 1911, p. 62, 67). 
mandas por expansão e qualidade, sem, no entanto, assumir outras características do sistema comercial, como a busca por equilíbrio financeiro.

O segundo aspecto remete à questão do baixo número de assinantes do sistema telefônico de Belo Horizonte. Nos Estados Unidos, o alto preço do serviço telefônico é considerado um dos elementos que impediu, inicialmente, uma maior expansão do sistema pelo país. Claude Fischer informa que em 1888 o serviço telefônico custava, em Los Angeles, cerca de 10\% do salário médio de um empregado urbano. Em Boston as taxas eram cerca de 30\% mais caras. Somente quando as patentes estavam para expirar, a Bell Telephone começou a baixar os preços, os quais, mesmo assim, ainda faziam do telefone um serviço caro (Fischer, 1992, p. 38-40). Porém, a confiar nas informações do Prefeito Benjamim Jacob, as taxas no Rio de Janeiro e em São Paulo eram quase três vezes mais altas que na capital mineira, de $6 \$ 000$ mensais $^{19}$. Logo, entre os motivos que poderiam ser propostos para o baixo número de assinantes na capital mineira, o preço do serviço não parece ser um argumento sustentado pela documentação.

O número de assinantes parece ser, ao mesmo tempo, causa e consequência do fraco desenvolvimento do sistema telefônico da nova capital. Como afirmado, o telefone foi pensado originalmente como ferramenta para a otimização dos trabalhos da Comissão Construtora e, posteriormente, da administração municipal, que chamou a si a implantação, manutenção e gestão do sistema, descartando o modelo vigente em Ouro Preto e alhures. A expansão do sistema a assinantes particulares ocorreu apenas como reação à demanda dos primeiros habitantes da nova cidade, e talvez não seja descabido dizer que, embora a administração municipal tenha se empenhado em manter o sistema funcionando nas melhores condições possíveis, não o incluía entre suas prioridades.

Certamente, os já citados problemas técnico-operacionais dificultaram a expansão de uma tecnologia que, mesmo nos Estados Unidos, precisou de grandes esforços empresariais para convencer as pessoas de que aquele "brinquedo era uma ferramenta útil" e onde, "por décadas, a maioria dos homens do telefone - particularmente aqueles no marketing - acre-

19 Para efeito de comparação, em 1907 o menor nível de consumo estabelecido na tabela do serviço de energia elétrica (30 velas ou 12,6 KW-hora) era taxado em $8 \$ 400$ por mês na capital mineira (Relatório apresentado ao Conselho Deliberativo pelo Prefeito Benjamim Jacob em 23 de setembro de 1907, p. 71). 
ditavam que, para vender seu produto, eles precisavam achar, ou criar, usos para ele" (Fischer, 1992, p. 65).

Um rápido levantamento nos periódicos publicados na capital durante suas primeiras décadas parece reforçar a impressão de que o telefone não se configurou, para os habitantes da nova capital mineira, em um artefato necessário. Numa coluna intitulada Indicadores de Bello Horizonte, publicada pelo jornal Actualidade no primeiro dia de 1906, há uma lista de figuras ligadas à administração pública e a serviços típicos de uma cidade construída sob a égide da burocracia estatal. Dela constam 2 secretários, 13 desembargadores, 1 procurador-geral, 1 juiz de direito, 1 juiz substituto, 1 promotor público, 1 subprocurador, 1 chefe de polícia; 22 advogados, 8 médicos e 5 procuradores. Todos listados com seus endereços de contato; nenhum deles apresenta um número de telefone associado (Actualidade, 1 jan. 1906). Isso, quase 15 anos depois de instalado o sistema telefônico, parece indicar que este não era considerado imprescindível para a atuação daqueles profissionais. Esta e outras questões ligadas à recepção e ao uso do telefone em caráter privado - comercial ou particular - demandam maiores investigações para que o quadro histórico possa ser mais bem delineado.

Depois de várias tentativas de equilibrar a receita gerada e a despesa exigida pelo sistema telefônico da capital, a administração municipal adotou o modelo mais comum que vigorava em Minas Gerais e no Brasil: a concessão do serviço a empresas comerciais particulares. Em seu relatório ao Conselho Deliberativo, o prefeito justificou a mudança de postura do governo municipal:

A Prefeitura explorava diretamente os serviços de iluminação elétrica pública e particular, de telefones e de distribuição de força motriz às indústrias, utilizando-se para isso das instalações de Freitas e de Rio de Pedras, feitas pelo governo do Estado e por ela. A execução desses serviços pelos governos estaduais e municipal, justificava-se por se tratar de uma cidade novíssima, onde não havia ainda campo para o emprego de capitais estranhos. Hoje, porém, graças ao seu extraordinário desenvolvimento, Belo Horizonte é outra e seus serviços elétricos perderam a feição acanhada dantes e exigiam maior amplitude e completo remodelamento para ficarem na altura de bem servir à cidade. Esta foi uma das principais razões da atual administração ter promovido e realizado o arrendamento, cujo contrato foi publicado no “Minas Gerais”. De 21 de março para cá, os serviços elétricos 
atravessam uma fase de reorganização tanto no seu material fixo e rodante como nos seus processos administrativos; e será necessário algum tempo ainda para que se normalizem, pois são grandes as reformas no material, previstas e exigidas pelo contrato de 21 de março do corrente ano. (Relatório apresentado aos Membros do Conselho Deliberativo da Capital pelo Prefeito Dr. Olyntho Deodato dos Reis Meirelles em setembro de 1912, p. 41)

E, mais à frente, oferecia um quadro otimista do desenvolvimento futuro do sistema telefônico na capital de Minas Gerais:

O serviço telefônico, precário até pouco tempo, vai, como os demais, se desenvolvendo extraordinariamente. Atualmente tem 500 assinaturas, todas tomadas, havendo já requisição para grande número. A Empresa já providenciou, encomendando outro quadro para 500 linhas. Com a regularização dos atuais motores e com a montagem da $3^{a}$ unidade do Rio das Pedras, e reparos da Usina de Freitas, o quadro de distribuição de energia elétrica estará provido para atender às necessidades crescentes de Belo Horizonte. A grande cópia do material encomendado pela Diretoria de Eletricidade antes da assinatura do contrato e que, por disposição do mesmo, deve ser entregue à Empresa, vai se fazendo à medida que vai chegando aqui. (Relatório apresentado aos Membros do Conselho Deliberativo da Capital pelo Prefeito Dr. Olyntho Deodato dos Reis Meirelles em setembro de 1912, p. 42)

A justificativa para a concessão, portanto, entrelaça o desenvolvimento da cidade à demanda por maior eficiência dos serviços prestados à população - discurso alinhado à concepção liberal vigente em vários ć́rculos das elites letradas brasileiras, ainda que nem sempre seguido à risca pelas lideranças mineiras. A disputa pela concessão dos serviços urbanos da capital mineira mobilizou grandes interesses. Segundo Octavio Penna, em 27 de dezembro de 1911 a Prefeitura recebeu "propostas de Guinle \& Cia., Light and Power, Augusto F. Ramos \& Gabriel Chouffour, Vivaldi \& Cia., Sampaio Corrêa \& Cia. para arrendamento ou cessão dos serviços de luz, bondes e telefones da Capital". Em 10 de fevereiro de 1912, foi anunciado o resultado do processo, sendo aceita a proposta da empresa Sampaio Corrêa \& Cia, com a qual foi assinado o contrato acima citado, em 21 de março de 1912 (Penna, 1997, p. 125-128).

Essa firma, com sede no Rio de Janeiro, estava em ascensão: no ano de 1911 já havia conseguido a concessão para a construção de uma 
estrada de ferro no Estado do Rio de Janeiro, para a qual firmou parceria com uma empresa francesa (Decreto n. 8.673, de 12 de abril de 1911; Decreto n. 8.831, de 10 de julho de 1911), bem como outra no Estado de São Paulo (Decreto n. 9.003, de 4 de outubro de 1911), em parceria com investidores brasileiros ${ }^{20}$. Foi fundada uma empresa específica na capital, para levar avante a concessão dos negócios, envolvendo figuras de importância regional. Seu presidente, Manuel Tomás de Carvalho Brito, "mesclava com sucesso as carreiras de político, tecnocrata e empresário", tendo ocupado diversos cargos eletivos e administrativos no estado de Minas Gerais (Eakin, 2001, p. 84) ${ }^{21}$.

Um significativo detalhe sugere que o telefone permaneceria, ainda sob a nova arrendatária, em segundo plano: a empresa formada para gerenciar os serviços arrendados passou a se chamar "Empresa de Eletricidade eViação Urbana de Minas Gerais” (Barreto, 1950, p. 194). Sem menção ao serviço telefônico, portanto.

\section{Conclusão: fios a perseguir}

Este trabalho é parte de uma pesquisa em desenvolvimento, visando compreender o uso social dos artefatos tecnológicos pela sociedade mineira no início do século XX. O objetivo é perceber como se deu a recepção e utilização dessas tecnologias desenvolvidas em outros lugares e culturas, e qual o significado que tais objetos adquiriram em Minas Gerais. Neste artigo foi abordado o processo de implantação do telefone e seu funcionamento na nova capital do Estado, em seus primeiros anos. Embora ainda incipiente, a pesquisa permite delinear algumas conclusões e revela fios a desenrolar.

20 José Mattoso Sampaio Corrêa representa bem o tipo de personagem que Eakin afirma ser típico do capitalismo brasileiro, transitando entre diferentes espaços da esfera pública (Eakin, 2001, p. 19): engenheiro civil, lente da Escola Polytechnica e professor do Curso de Engenharia Civil, membro do Club de Engenharia, secretário do Instituto Polytechnico Brasileiro (Almanack Laemmert, 1911, p. 197 ss.). Agradeço à professora doutora Rita Almico a indicação dessas informações.

21 Deputado estadual, deputado federal, senador estadual, secretário de Finanças, secretário do Interior e da Justiça; proprietário da Companhia Fiação e Tecelagem de Minas Gerais (Eakin, 2001, p. 84). 
O telefone, na então Cidade de Minas, foi implantado por uma administração que detinha amplos poderes sobre o ambiente urbano, o qual se constituía por ato e força de decisões políticas. O Estado chamou a si a gestão do sistema, contrariando as práticas adotadas para o funcionamento do telefone em outras cidades mineiras, incluindo a antiga capital, Ouro Preto, e mesmo o difuso discurso liberal alardeado pelas elites políticas e econômicas regionais. Essa característica peculiar do sistema belorizontino ajuda a explicar a evidente tensão entre o objetivo original, de atendimento às instâncias administrativas da cidade, e as dificuldades geradas pela ampliação do sistema visando atender demandas particulares, que se manifesta nas precárias condições de funcionamento e no relativamente baixo número de usuários particulares do sistema em seus primeiros anos de funcionamento.

Há outras questões a perseguir, como a análise das questões orçamentárias e a busca por outros documentos que iluminem o lugar do serviço telefônico dentro do conjunto da burocracia estatal.A ampliação do recorte temporal para o período de administração privada do sistema ajudará a compreender o uso social do telefone pelos habitantes da cidade. Isso demandará a busca, em novos acervos documentais, pelos vestígios da atuação da empresa concessionária em Belo Horizonte.

Enfim, a pesquisa permite perceber que o difundido discurso do telefone como "sinal visível de civilização", cuja existência e cujo uso contribuem para o caráter moderno da cidade, ao ser confrontado com informações do cotidiano, aponta para uma inserção tímida desse artefato no cotidiano da nova capital mineira.Ao menos em seus primeiros anos.

\section{Fontes documentais}

\section{Relatórios de prefeitos ao Conselho Deliberativo: 1899-1912}

IMPRENSA Oficial (Minas Gerais). Mensagem ao Conselho Deliberativo da Cidade de Minas. Apresentada em 19 de setembro de 1900 pelo Prefeito Dr. Bernardo Pinto Monteiro. Cidade de Minas: Imprensa Oficial do Estado de Minas Gerais, 1900.

IMPRENSA Oficial (Minas Gerais). Relatório apresentado ao Conselho Deliberativo pelo Prefeito Dr. Bernardo Pinto Monteiro. 12 de setembro de 1899-31 de agosto de 1902. Belo Horizonte: Imprensa Oficial de Minas Gerais, 1902. Disponível em <http:// portalpbh.pbh.gov.br/pbh/ecp/comunidade.do?evento $=$ portlet $\& \mathrm{pIdPlc}=\operatorname{ecpTaxo}$ 
nomiaMenuPortal $\&$ app $=$ fundacaocultura $\&$ tax $=6762 \& 1$ ang $=$ pt_ $\mathrm{BR} \& \mathrm{pg}=5520 \& \operatorname{taxp}=0 \& / \mathrm{pbh} /$ contents.do?evento $=$ conteudo\&lang $=\&$ idConteu $\mathrm{do}=24192 \& \mathrm{chPlc}=24192>$. Acesso em 20/4/2017.

IMPRENSA Oficial (Minas Gerais). Relatório apresentado ao Conselho Deliberativo da Cidade de Bello Horizonte pelo Prefeito Francisco Bressane de Azevedo em 16 de setembro de 1903. Belo Horizonte: Imprensa Oficial de Minas Gerais, 1903.

IMPRENSA Oficial (Minas Gerais). Relatório apresentado ao Conselho Deliberativo da Cidade de Bello Horizonte pelo Prefeito Francisco Bressane de Azevedo em setembro de 1905. Belo Horizonte: Imprensa Oficial de Minas Gerais, 1905.

IMPRENSA Oficial (Minas Gerais). Relatório apresentado aos Srs. Membros do Conselho Deliberativo pelo Prefeito Interino Dr. Antonio Carlos Ribeiro de Andrada. Belo Horizonte: Imprensa Oficial do Estado de Minas Gerais, 1905.

IMPRENSA Oficial (Minas Gerais). Relatório apresentado ao Conselho Deliberativo da Cidade de Belo Horizonte pelo Prefeito Interino Dr. Antonio Carlos Ribeiro de Andrada em setembro de 1906. Belo Horizonte: Imprensa Oficial de Minas Gerais, 1906.

IMPRENSA Oficial (Minas Gerais). Relatório apresentado ao Conselho Deliberativo pelo Prefeito Benjamim Jacob em 23 de setembro de 1907. Belo Horizonte: Imprensa Oficial do Estado de Minas Gerais, 1907.

IMPRENSA Oficial (Minas Gerais). Relatório apresentado ao Conselho Deliberativo pelo Prefeito Benjamim Jacob em 16 de setembro de 1908. Belo Horizonte: Imprensa Oficial do Estado de Minas Gerais, 1908.

IMPRENSA Oficial (Minas Gerais). Relatório apresentado ao Conselho Deliberativo pelo Prefeito Benjamin Brandão em janeiro de 1910, dispõe sobre assumptos referentes ao ano decorrido de agosto de 1908 a setembro de 1909. Belo Horizonte: Imprensa Oficial do Estado de Minas Gerais, 1910.

IMPRENSA Oficial (Minas Gerais). Relatório apresentado ao Conselho Deliberativo com o projeto de orçamento para 1911 pelo Prefeito Dr. Olyntho Meirelles em novembro de 1910. Belo Horizonte: Imprensa Oficial do Estado de Minas Gerais, 1910.

IMPRENSA Oficial (Minas Gerais). Relatório apresentado ao Conselho Deliberativo pelo Prefeito Dr. Olyntho Deodato dos Reis Meirelles em 16 de setembro de 1911. Belo Horizonte: Imprensa Oficial do Estado de Minas Gerais, 1911.

IMPRENSA Oficial (Minas Gerais). Relatório apresentado aos Membros do Conselho Deliberativo da Capital pelo Prefeito Dr. Olyntho Deodato dos Reis Meirelles em setembro de 1912. Belo Horizonte: Imprensa Oficial do Estado de Minas Gerais, 1912.

\section{Coleção de leis do Conselho Deliberativo de Belo Horizonte: 1900-1914}

IMPRENSA Oficial (Minas Gerais). Colleç̧ão de Leis do Conselho Deliberativo de Bello Horizonte. De fevereiro a dezembro de 1912: ns. 54 a 62. Belo Horizonte: Imprensa Oficial do Estado de Minas, 1912.

IMPRENSA Oficial (Minas Gerais). Colleç̧ão de Leis do Conselho Deliberativo de Bello 
Horizonte - 1913: ns. 63 a 72. Belo Horizonte: Imprensa Oficial do Estado de Minas, 1913.

IMPRENSA Oficial (Minas Gerais). Collecção de Leis do Conselho Deliberativo de Bello Horizonte. De 1900 a 1911: ns. 1 a 53. Portaria n. 60. Belo Horizonte: Imprensa Oficial do Estado de Minas, 1922.

PREFEITURA de Bello Horizonte. Leis. De ns. 73 a 85. Belo Horizonte: Imprensa Oficial do Estado de Minas, 1926.

\section{Outros documentos}

A CAPITAL. 1913. Biblioteca Universitária (UFMG). Acervo Coleção Linhares Digital - UFMG. Disponível em <http://linhares.eci.ufmg.br/index.php?status=3>. Acesso em 20/4/2017.

ACTUALIDADE. 1906. Biblioteca Universitária (UFMG). Acervo Coleção Linhares Digital - UFMG. Disponível em <http://linhares.eci.ufmg.br/index.php?status=3>. Acesso em 20/4/2017.

AEROPLANO. 1913. Biblioteca Universitária (UFMG). Acervo Coleção Linhares Digital - UFMG. Disponível em <http://linhares.eci.ufmg.br/index.php?status=3>. Acesso em 20/04/2017.

ALMANACK Laemmert: Administrativo, Mercantil e Industrial. Rio de Janeiro, 1911. Biblioteca Nacional. Disponível em <http://memoria.bn.br/hdb/periodico.aspx>. Acesso em 20/4/2017.

ARQUIVO Público (Belo Horizonte). Faturas de compras de aparelhos e acessórios para telefonia. Rio de Janeiro, de 18/03/1896 a 30/03/1897. Notação AI.01.02.02 - 139. Arquivo Público da Cidade de Belo Horizonte.

ARQUIVO Público (Belo Horizonte). Pasta 54(B) - Telefone. Arquivo Público da Cidade de Belo Horizonte.

ARQUIVO Público Mineiro. Acervo da Comissão Construtora da Nova Capital de Minas. Disponível em <http://comissaoconstrutora.pbh.gov.br/>. Acesso em 20/4/2017.

BIBLIOTECA Universitária (UFMG). Actualidade, 1906. Acervo Coleção Linhares Digital - UFMG. Disponível em <http://linhares.eci.ufmg.br/index.php?status=3>. Acesso em 20/4/2017.

BIBLIOTECA Universitária (UFMG). A Capital, 1913. Acervo Coleção Linhares Digital - UFMG. Disponível em <http://linhares.eci.ufmg.br/index.php?status=3>. Acesso em 20/4/2017.

BIBLIOTECA Universitária (UFMG). Aeroplano, 1913. Acervo Coleção Linhares Digital - UFMG. Disponível em <http://linhares.eci.ufmg.br/index.php?status=3>. Acesso em 20/4/2017.

BRASIL. Decreto n. 8.673 - de 12 de abril de 1911. Autoriza a transferência, ao engenheiro José Mattoso Sampaio Corrêa ou à companhia que organizar, do contrato para a construção e arrendamento do prolongamento da Estrada de Ferro de Maricá, 
de Nilo Peçanha a Iguaba Grande. Senado Federal, Secretaria de Informação Legislativa. Disponível em < http://legis.senado.gov.br/legislacao/ListaTextoIntegral. action?id=43002 $>$. Acesso em 20/4/2017.

BRASIL. Decreto n. 8.831 - de 10 de julho de 1911. Concede autorização à Compagnie Générale de Chemins de Fer des Etats Unis du Brésil para funcionar na República. Senado Federal, Secretaria de Informação Legislativa. Disponível em <http://www2.camara.leg.br/legin/fed/decret/1910-1919/decreto-8831-10-julho-1911-525575-publicacaooriginal-1-pe.html>. Acesso em 20/4/2017.

BRASIL. Decreto n. 9.003 - de 4 de outubro de 1911. Transfere a Paulo Affonso Orozimbo de Azevedo, Dr. José Mattoso Sampaio Corrêa e Henrique Palm, ou à firma, companhia ou empresa que os mesmos organizarem, a concessão feita a Paulo Orozimbo de Azevedo para construção de uma estrada de ferro colonial. Senado Federal, Secretaria de Informação Legislativa. Disponível em $<$ http://legis.senado. gov.br/legislacao $/$ ListaTextoIntegral.action?id=37964\&norma $=53673>$. Acesso em 20/4/2017.

CONGRESSO dos EUA. Reconhecimento do registro do telefone por Antonio Meucci. 11 jun. 2002. Disponível em <https://www.congress.gov/bill/107th-congress/house-resolution/269/text.> Acesso em 28/10/2017.

IMPRENSA Oficial (Minas Gerais). Collecção das Leis e Decretos do Estado de Minas Gerais, 1898. Cidade de Minas: Imprensa Oficial do Estado de Minas Gerais, 1899.

IMPRENSA Oficial (Minas Gerais). Collecção das Leis e Decretos do Estado de Minas Gerais, 1899. Cidade de Minas: Imprensa Oficial do Estado de Minas Gerais, 1900.

O PHAROL, 1883. Setor de Memória da Biblioteca Municipal Murilo Mendes. Juiz de Fora (MG).

PREFEITURA de Belo Horizonte. Acervo da Comissão Construtora da Nova Capital de Minas. Disponível em <http://comissaoconstrutora.pbh.gov.br/>. Acesso em 20/4/2017.

SENNA, Nelson Coelho de. Annuario Historico-Chorographico de Minas Geraes. Belo Horizonte: Imprensa Oficial, 1906, 1907, 1909, 1911, 1913, 1918.

\section{Referências bibliográficas}

BARRETO, Abílio. Resumo histórico de Belo Horizonte (1701-1947). Belo Horizonte: Imprensa Oficial, 1950.

BARRETO, Abílio. Belo Horizonte: memória histórica e descritiva - história média. Belo Horizonte: Fundação João Pinheiro/Prefeitura de Belo Horizonte, 1995.

BERTHOLD,Victor Maximilian. History of thelephone and telegraph in Brazil, 1851-1921. New York: American Telephone and Telegraph Company, 1922 (reimpressões da coleção da Universidade de Michigan).

CASSON, Herbert N. The history of the telephone. New York: Cosimo Classics, 2006 (1910). 
DROPS. Disponível em <https://en.wikipedia.org/wiki/Drop_\%28telecommunication\%29>. Acesso em 20/4/2017.

DULCI, Otávio Soares. Política e recuperação econômica em Minas Gerais. Belo Horizonte: Editora UFMG, 1999.

DUTRA, Eliana de Freitas (org.). Belo Horizonte: horizontes históricos. Belo Horizonte: C/Arte, 1996.

EAKIN, Marshall C. Tropical capitalism: the industrialization of Belo Horizonte, Brazil. New York: Palgrave, 2001.

EDGERTON, David. The shock of the old: technology and global history since 1900 . London: Profile Books, 2008.

FISCHER, Claude S. America calling: a social history of the telephone to 1940. Berkeley: University of California Press, 1992.

FUNDAÇÃO Telefônica. Tão longe, tão perto: as telecomunicações e a sociedade. São Paulo: FAAP - Fundação Armando Álvares Penteado, 2010.

GOODWIN JR., James William. Cidades de papel: imprensa, progresso e tradição. Diamantina e Juiz de Fora, MG (1884-1914). Belo Horizonte: Fino Traço, 2015.

JULIÃO, Letícia. Belo Horizonte: itinerários da cidade moderna (1891-1920). In: DUTRA, Eliana (org.). Belo Horizonte: horizontes históricos. Belo Horizonte: C/Arte, 1996, p. 49-118.

LIMA, Bárbara Braga Penido. Affonso Penna e os repertórios do engrandecimento mineiro (1874-1906). Belo Horizonte: CEFET-MG, 2016 (Dissertação de Mestrado em Educação Tecnológica).

MARTINS FILHO,AmílcarVianna (org.). Novo dicionário biográfico de Minas Gerais: 300 anos de história. Belo Horizonte: Instituto Cultural Amílcar Martins, 2013.

MARVIN, Carolyn. When old technologies were new: thinking about electric communication in the late nineteenth century. Oxford: Oxford University Press, 1988.

MELLO, Ciro Flávio Bandeira de. A noiva do trabalho - uma capital para a República. In: DUTRA, Eliana (org.). Belo Horizonte: horizontes históricos. Belo Horizonte: C/Arte, 1996, p. 11-47.

MILLER, Daniel. Trecos, troços e coisas. Estudos antropológicos sobre a cultura material. Rio de Janeiro: Zahar, 2013.

PAULA, João Antônio de. Raízes da modernidade em Minas Gerais. Belo Horizonte: Autêntica, 2000 (Coleção Historial).

PENNA, Octavio. Notas cronológicas de Belo Horizonte. Introdução de Berenice Martins Guimarães. Belo Horizonte: Fundação João Pinheiro, 1997.

RIBEIRO, Luiz Cesar de Queiroz. Transferências, empréstimos e traduções na formação do urbanismo no Brasil. In: RIBEIRO, Luiz Cesar de Queiroz; PECHMAN, Robert Moses (org.). Cidade, povo e nação: gênese do urbanismo moderno. Rio de Janeiro: Civilização Brasileira, 1996, p. 15-21.

SALGUEIRO, Heliana Angotti. Engenheiro Aarão Reis: o progresso como missão. Belo Horizonte: Fundação João Pinheiro, 1997. 
SMIL,Vaclav. Creating the twentieth century: technical innovations of 1867-1914 and their lasting impact. Oxford: Oxford University Press, 2005.

UEDA, Vanda. Inovação tecnológica e espaço urbano: a implantação da Companhia Telefônica Melhoramento e Resistência em Pelotas, RS. Florianópolis: Departamento de Geografia, Universidade Federal de Santa Catarina, 1998 (Dissertação de Mestrado em Geografia).

VARIA Historia. Belo Horizonte - cem anos em cem. Belo Horizonte, FAFICH-UFMG, n. 18 , nov. 1997.

VEIGA, José Pedro Xavier da. Efemérides mineiras, 1664-1897. Belo Horizonte: Fundação João Pinheiro, 1998, 2 v. 